\title{
Sustainable Brand Management of Alimentary Goods
}

\author{
Jana Majerova ${ }^{1, *(\mathbb{D})}$, Wlodzimierz Sroka ${ }^{2,3}$, Anna Krizanova ${ }^{1}$, Lubica Gajanova ${ }^{1} \mathbb{D}$, \\ George Lazaroiu ${ }^{4}$ and Margareta Nadanyiova ${ }^{1}$ (1) \\ 1 Department of Economics, Faculty of Operation and Economics of Transport and Communications, \\ University of Zilina, Zilina 026 01, Slovakia; anna.krizanova@fpedas.uniza.sk (A.K.); \\ lubica.gajanova@fpedas.uniza.sk (L.G.); margareta.nadanyiova@fpedas.uniza.sk (M.N.) \\ 2 Management Department, WSB University, Dabrowa Gornicza 41-300, Poland; WSroka@wsb.edu.pl \\ 3 North-West University, Potchefstroom 2351, South Africa \\ 4 Department of Economic Sciences, Spiru Haret University, Bucharest 030045, Romania; \\ phd_lazaroiu@yahoo.com \\ * Correspondence: jana.majerova@fpedas.uniza.sk; Tel.: +421-41-513-3099
}

Received: 20 November 2019; Accepted: 9 January 2020; Published: 11 January 2020

\begin{abstract}
Sustainability of food production and consumption has become one of the most discussed topics of sustainable development in global context. Thus, traditional managerial patterns have to be revised according to the social request. The revisions that have been done so far are based on relevant specifics of production and have mostly general character. Moreover, traditional managerial postulates do not change; only their way of implementation is modified. These two facts are possible reason of the practical fails in sustainable management of alimentary goods. One of these traditional managerial concepts is brand. Within this context, it has been considered as a facilitator of CSR (corporate social responsibility) activities. But the situation has changed, and the suspicion that brand loyalty is not a facilitator but an obstacle to the sustainable management is high. Thus, the importance of research of brand loyalty in scope of sustainable management of alimentary goods is indisputable. According to the above mentioned, the main goal of the contribution is to identify relevant brand value sources of loyalty in scope of sustainable brand management of alimentary goods. To achieve this, the factor analysis has been applied to provide statistical evaluation of data obtained from our own questionnaire survey. We have found out that components of brand value sources do not vary when comparing brands and those without loyal consumers. Based on this, appropriate recommendations for the theory and practice of sustainable brand management of alimentary goods have been formulated.
\end{abstract}

Keywords: brand; branding; brand management; sustainability; alimentary goods; brand loyalty

JEL Classification: Q01; M11; M31

\section{Introduction and Current Situation Insight}

Contemporary scientific literature highlights the importance of corporate social responsibility in the sustainable management process, not only in general, but also regarding the sectoral specifics of production [1-3]. Thus, according to this trend, producers of alimentary goods should put moral pressure on their suppliers, and consumers should be more involved in their buying decision processes [4]. In order to achieve these changes in so far functioning stereotypes, the issue of brand and brand management should be highlighted. But the fact that alimentary goods are characterized by traditional habitual buying behavior creates a specific obstacle to such an approach, because the reason is that, in this type of buying behavior, consumer's loyalty is the leading motivation for purchase whether or not the brand is socially responsible on the market $[5,6]$. The above-mentioned fact can 
be considered as a real problem when seeking to achieve sustainability in scope of food production and consumption. The main reason for this is that brand managers of alimentary goods in case of brands subjectively perceived as valuable are not motivated enough to act responsibly towards society, and consumers are not motivated to play active role in the process of information searching [7]. In this case, socially responsible activities are not directly connected with desired effect, even if they are applied in accordance with contemporary state of knowledge. While the main theoretical attention is generally paid to the issue of facilitators of sustainable management, practice shows the need of application of an opposite approach - that is, a focus on possible obstacles to optimal implementation of managerial patterns. Thus, it is vital to change the approach and to focus not on the facilitators but on the contrary, also on the obstacles to sustainable development. Only when these barriers are identified will it be possible to manage them and to eliminate their negative impacts on the effectiveness of sustainable management. Thus, the irony is, on the one hand, the phenomenon of consumer loyalty can be considered as a stimulus, and on the other hand, as an obstacle to sustainable performance of brands on alimentary goods market. According to this fact, it is vital to analyze value sources of brands characterized by presence vs. absence of consumer loyalty and to apply a conscious and responsible approach to the consumer's loyalty as one of the leading buying behavior motivations.

Thus, this article focuses on the meaning of brand loyalty research in the scope of sustainable management of alimentary goods. The first part of the article analyses interactions between loyalty and sustainable brand management in general, as well as in case of alimentary goods. This is followed by a methodological part of the article where the main postulates of the article as well as factor analysis and relevant statistical tests are described. The next part synthetizes obtained results formulated on the basis of detected discrepancies in value sources of brands characterized by presence vs. absence of consumer's loyalty. The discussion is also an immanent part of the article and it is included in the same part as results of the research itself. The last part contains the summary of the main results and outcomes of research with implications for the future.

The conceptualization of the research is as follows: (1) literature review and current situation summary; (2) formulation of original presumptions of authors; (3) creation of the model of research based on questionnaire survey; (4) realization of the research itself; (5) statistical testing and evaluation of obtained data; (6) formulation of conclusions and managerial implications, and (7) critical consideration of framework conditions of applicability of the research outcomes, obstacles and limits of the research, and possible ways of further research in scope of sustainable brand management of alimentary goods. Doing all the mentioned activities while respecting the contemporary state of knowledge in the area of brand management, corporate social responsibility, strategic management, and statistics.

\section{Literature Review and Theoretical Background of Research Itself}

In recent decades, many researches in scope of the complex issue of corporate social responsibility have been carried out. However, it is still necessary to continue investigating its benefits and causalities in scope of marketing [8]. Thus, nowadays, it is crucial that the attention is paid to the impact of contemporary global trends on the practical aspects of managerial challenges stimulated by incorporation of the concept of corporate social responsibility. The reason is the assumption that it affects significantly the success of each company and its competitiveness by modifying traditional managerial patterns according to the postulates of corporate social responsibility [9]. Until now, the research has investigated this issue separately, without any deeper interactions with overall managerial framework. The representative example of such an approach is a huge scientific school focused on the analysis of supply chain management and its importance in sustainable management. It has been concluded that such an approach is insufficient, and formulated advices for managers should be revised according to the wider consequences of implementation of sustainable management [10]. Despite this fact, the importance of sustainable supply chain management as an immanent part of corporate social responsibility with significant impact on consumer buying behavior is indisputable. The reason is that consumers adapt supply chain practice to the real socially responsible behavior of the company 
and they perceive their own value across the prism of the market performance of the company and its transformation into real corporate citizenship [11]. So it is obvious that brands strongly affect overall sustainable development of the society as they can be considered as a powerful tool to create and maintain public opinion [12]. According to the above mentioned, brands are becoming parts of people's lives all over the world. They form an immanent part of human beings' reality and they co-act in the process of own value creation as they have strong interpretation power about their consumers [13]. Moreover, brands have become a very effective tool of communication. By these, consumers inform other members of their social group who they are and if they really belong to a specific social group. It is a way to communicate one's own social status and life values. Thus, once the brand starts to be perceived as valuable from the point of view of selected group of consumers, it is very likely that this group starts to be identified with this brand and all the group members will transform into loyal consumers who consider such a brand as subjectively valuable for them. A logical consequence of this situation is that there will be many benefits, like less price sensitivity, lower need of communication activities of such a brand, less critical approach towards quality, and so forth. Thus, a loyal consumer is a dream of each brand manager because only by personalizing a consumer with a brand, can brand management be considered as really effective. However, there is not only a one-way influence between brand and consumers. While, at the beginning, the brand is created by consumers, very shortly after creating a loyal consumer platform, consumers start to be modified by the brand. It means that the brand has potential to change social attitudes and life values and it is willing to be the real tool of social change leading to the sustainable development [14]. Thus, brands characterized by their environmental conformity can be transformed into a strong tool to learn who their consumers are. On the one hand, there is a huge amount of brands who are primarily focused on already environmentally oriented consumers, but on the other hand, there are many more brands (traditionally perceived as valuable and significant for selected social groups) that can change the environmental orientation of their consumers [15]. In scope of the above mentioned, it is vital to pay attention to the detailed segmentation of consumers. The reason is that the segment of socially responsible consumers can vary internally according to the highlighted green attitudes connected to brands. It means that there is at least a double construct of a socially responsible consumer: (1) a consumer who is really internally environmentally oriented and who prefers socially responsible brands when making a buying decision and (2) a consumer whose environmental attitudes are only derived and narrowly connected with the essence of his/her favorite brand. The main difference between these two types of consumers lies in the fact that, while in the first case, socially responsible orientation of the brand is the key attribute of its brand value building, in the second case, such a consumer does not prefer socially responsible brands automatically as it is only consequence of long-term subjectively perceived brand value and the main motive for brand value substitution would not be its replacement by a more environmentally friendly brand. Thus, it is vital to identify real internal attitudes of consumers and to discover if the subjectively perceived brand value is reason or consequence of its socially responsible market behavior [16]. So the main task for managers of not only formally but really sustainably manageable brands is to identify internal motives and brand value sources of their consumers and to co-act in the process of market education as one of the prerequisites of socially sustainable development [17].

One of possible tools to achieve this state is to apply a conscious and responsible approach to the consumer's loyalty and its creation through brand management [18]. The reason of such a postulate is that the traditional educational model of consumers (push model) has failed and thus, it is necessary to apply the opposite one (pull model). The main idea of such a model lies in identification of appropriate brand value sources of brands characterized by loyal and nonloyal attitudes and in subsequent usage of relevant brand loyalty sources (brand value sources in case of loyal brands) for purposes of sustainable management. Thus, subconscious consumers' education would be applied-that is, brands will affect consumer's environmental attitudes through existing brand value sources, and this change in attitudes will affect their general attitudes towards sustainable development of society. Unless this is done, the consumer's loyalty can be, in specific product categories, considered as a significant obstacle 
to the development of sustainable management and corporate social responsibility. That is why companies who are devoting significant resources to socially responsible activities, insights into the optimal formulation, implementation, and effectiveness estimation of socially responsible strategies are nowadays still on the crossroad [19].

Although the scientific literature clearly stated strong positive correlation between corporate social responsibility implementation into strategic management of the company and its positive image, the individual processes and mechanisms which are relevant from the point of view of this positive effect creation have not been analyzed in details so far [20]. Although the possible significant impact of psychographic characteristics of consumers on the process of a brand's positive image creation has been highlighted, there is a scientific gap lying in the need of the mechanisms of behavioral economics investigation [21]. In scope of the above mentioned, Song et al. focused on the identification of a relationship between selected structural associations and brand loyalty. They provided a case study on the example of coffee shop brands. As a result of the scientific effort of Song et al., it has been discovered that the phenomenon of so-called love brands is extremely effective in the process of brand loyalty creation and management [22]. Other researches have proven the significance of brand satisfaction and brand trust in the process of brand loyalty creation and maintenance $[23,24]$. On the other hand, not only the impact of selected subjectively perceived brand value sources on the brand loyalty has been investigated, but also the impact of brand loyalty and its value sources on the effectiveness of brand social responsibility has been analyzed. As a result, it has been concluded that brand loyalty is essential in the process of sustainable brand management implementation via systematic manipulation with (1) attitudinal loyalty, (2) expenditure level, and (3) intention to buy and recommend [25].

Since the very beginning of brand loyalty research, authors have examined separately purchase loyalty and attitudinal loyalty as two main aspects of brand loyalty. Recently, the first of them has been connected with factual brand performance, while the second one has been described as only a hypothetical construct of brand loyalty without significant impact on brand performance on the market [26]. This research rejected the original concept of dual structure of brand loyalty, which was constructed on the presumption of the meaning of attitudinal loyalty as a key issue in the pricing fences setting [27].

In addition to this dual approach to the brand loyalty research, also another one has been applied - brand as a way to build loyalty and loyalty as a way to build a brand. Bhattacharya and Sen have determined the conditions under which consumers enter into an emotional relationship with brands. Based on this, they have detected loyalty as one of the presumptions of subjectively perceived brand value. Thus, they have applied the opposite concept to the so far implemented. According to this, Bhattacharya and Sen doubt subjectively perceived brand value as an antecedent of brand loyalty creation [28]. Following this approach, Stocchi and Fuller identified brand loyalty with the main brand equity source, discussing different segments of consumers and different markets [29]. In their approach, we can see another dimension of brand loyalty research because they draw from the general approach and they also apply a diversified approach. They conclude that difference in ranking of individual brand value sources (not only its quantity but also quality) perceived by loyal and nonloyal consumers exists.

Thus, also the relationship between the sources of sustainable brand value management and brand loyalty is analyzed [30]. It has been found that there is a positive correlation between (1) sustainable brand management and brand attitude; (2) brand attitude and brand loyalty, and (3) brand loyalty and sustainable brand management [31]. This conclusion is essential as so far, the authors have mainly stated that sustainable management has a positive impact on perceived brand value. The key importance of brand loyalty in this process has not been detected until now. Moreover, it has been also highlighted that the concept of brand value and its patterns could vary across socio-cultural specifics of consumers. It means that the need of focusing on the consumers at the regional basis has been stated. According to this trend, contemporary research not only highlights the importance of consumer loyalty 
in the process of brand management in general, but authors also focus on identification of sources of brand loyalty across markets (in both product and regional prospective) [32,33].

Chatzipanagiotou et al. have applied a cross-cultural approach to the analysis of brand value sources [34]. They state that most of the so far created models of brand value building and managing are very simple and they do not take into account the complexity of relevant factors. As such a factor, it is identified also the consumer behavior and its individuality and difficult predictability due to the rejection of the traditional neoclassical concept of so-called Homo Oeconomicus. So, they have constructed regression model with significant factors affecting the final subjectively perceived brand value as well as they have identified critical points of this model implementation when applying it to cross-cultural environment. Regional specifics in perception of brand value sources with implications to brand loyalty have been discussed by Sukalova et al., Tamuliene and Pilipavicius, Rozgina, Jain and Zaman, and Christodoulides et al. These authors have verified the effectiveness of traditional Aaker's quadratic model of brand value sources in the wider perspective of unified European single market as well as individual national markets, formulating advices for the practice of international brand value management [35-39].

Not only regional but also sectoral specifics are relevant for the research of interactions between brand loyalty and sustainable management. Rather et al. focused in their research on sectoral specifics of brand loyalty using factor analysis [40]. They have developed an integrated model of brand loyalty building based on the consumer's perception of identified key brand value sources (brand commitment, brand trust and brand satisfaction).

Emotional attributes of brand loyalty in general (not respecting product or regional prospective but focusing on the pure nature of brand value sources in scope of consumer's characteristics) have been analyzed by Poushneh and Vasquez-Parraga [41]. On the one hand, they have removed the traditional heterogeneous approach, but on the other hand, they have incorporated another selective criterion-consumer typology. This approach follows the research which examined the changes in brand loyalty over time, a case study of plenty of product categories worldwide [42].

Since then, product categories have been analyzed mainly separately, focusing on these product categories where the loyalty can be considered as main motivation of buying behavior due to the capital demanding of the purchase [43]. Previously, customer satisfaction and image were priority proven as the main attributes of brand loyalty creation across product categorization. Unfortunately, only a few scientists have focused on their synergic effect and complex research of the mechanisms of causalities and correlations between customer satisfaction and image in the process of brand loyalty creation in the light and shadow of sustainable brand management [44]. One of these studies has formed the main premise for future research aimed to tourist services, as a significant subcategory of services where the decision-making process is based on rational pillars [45].

Similarly, the importance of brand loyalty in scope of corporate social responsibility has been analyzed in the banking sector. According to the results of this study, it has been proven that sustainable brand management directly influences brand image and brand value subjectively perceived by consumers. Moreover, dominant importance of brand loyalty in the process of sustainable brand management has been identified [46,47]. IT sector is another field where consumer's loyalty has been discussed as one of the pillars of CSR (corporate social responsibility) effectiveness [48]. Not only stating but also investigating the significance of consumer's loyalty has been the aim of the study provided in scope of luxury brands [49]. Generally, all above-mentioned researches focused on the identification of brand value sources relevant in scope of brand loyalty creation in a specific product category. The comparison of brand value sources in case of presence vs. absence of brand loyalty has not been done so far. However, contemporary trend in brand loyalty research indicate such an ideological change. On the contrary, research becomes more complex, trying to find common mechanisms in wider groups of brands.

Such a wider group of brands is also the category of so-called private label brands. Contemporary research of brand loyalty in case of this category escalates turbulently nowadays [50]. One of the trends 
identified in this field is the investigation of seasonality in brand loyalty, which has been detected by the practice of private label brands. Mainly in case of private label brands of alimentary goods has the observation of seasonality in consumer's preferences been really obvious [51]. This can be considered as a possible obstacle to sustainable brand management based on brand loyalty. This is because the variability in brand loyalty has not described in details so far, and thus, complex analysis of this phenomenon needs to be carried out [52]. Moreover, this fact partially rejects theoretical constructs based on presumption of positive effect of brand loyalty on the overall effectiveness of sustainable brand management. This is because such fluctuations in brand loyalty could affect negatively sustainable brand management activities. Thus, although many approaches to brand loyalty and its importance in sustainable management have been applied so far, there is still a scientific gap lying in the fact that brand loyalty is traditionally considered as a facilitator of corporate social responsibility while there are various indicators of the opposite-especially in the category of products characterized by habitual buying behavior.

In scope of the above mentioned, these research questions have been set:

(1) How are brand value sources of alimentary goods?

(2) What is the order of importance of these brand value sources and their components?

(3) Do these sources differ in case of brand loyalty absence vs. brand loyalty presence?

\section{Methodological Background}

According to the literature review above, the main aim of the article is to identify brand value sources of loyalty which are relevant to sustainable brand management of alimentary goods. To achieve this aim, we have used the data from our own research provided on the socio-demographically representative sample of 2000 respondents (sample without outliers and incompatible units was 697) during the first half of 2019. We conducted this research via a questionnaire survey in the form of computer-assisted web interviewing respecting the ICC/ESOMAR (International code on Market, Opinion and Social Research and Data Analytics). The questionnaire was administered in Slovak Republic among its inhabitants over 15 years of age who were asked to complete the questionnaire because of their legal working subjectivity. Thus, the main presumption of autonomous buying decision-making has been fulfilled. On the other hand, one of the limitations of general applicability of the research outcomes has been caused by this fact-that is, territorial applicability of the recommendations done on the basis of research outcomes only in scope of Slovak consumer's preferences. Thus, possible implementations of statements which result from research itself are applicable only in case of alimentary goods brands addressed to Slovak consumer (domestic or foreign). The questionnaire consisted of three parts with the following reasoning: (1) the first part covered the general socio-demographic profile of respondents; (2) the second part covered questions about perception of brand value sources generally, and (3) the third part covered questions about perception of brand value sources in details across the traditional typology of buying behavior and representative product categories.

To provide research of brand value sources in scope of buying behavior typology, the traditional quadratic typology of buying behavior has been used, where on the basis of the degree of engagement and differentiation, we can identify the following categories: (1) complex buying behavior (high involvement/significant differences between brands); (2) variety seeking behavior (low involvement/significant differences between brands); (3) dissonance-reducing buying behavior (high involvement/few differences between brands), and (4) habitual buying behavior (low involvement/few differences between brands) [53]. The last mentioned category is the category which is relevant for purposes of research of sustainable brand management of alimentary goods. Brand value sources are analyzed in their traditional structure defined by Aaker-that is, (1) imageries; (2) attitudes; (3) attributes, and (4) benefits. The components of brand value sources are set in accordance with provided 
literature review and with relevance to so far identified specifics of psychographic profile of Slovak consumers [54].

The model of brand value sources identified by Aaker was used in accordance with the provided literature review due to its general applicability regardless specifics of product categories formulated on the principle of typology of buying behavior. The reason is that the presented article is only a partial outcome of complex research aimed to verify the internal diversification in brand value sources, ranking in case of brand value presence vs. absence across four basic product categories. Brand value sources and their relevant components which have been, through the realized questionnaire survey, tested in scope of their importance across product categories relevant for the types of buying behavior are summarized in the Table 1 below.

Table 1. Coding of brand value sources and their components relevant to further research evaluation.

\begin{tabular}{|c|c|c|c|}
\hline \multirow{2}{*}{$\begin{array}{l}\text { Brand Value } \\
\text { Sources }\end{array}$} & \multirow{2}{*}{ Components of Brand Value Sources } & \multicolumn{2}{|c|}{ Code } \\
\hline & & Brand Loyalty Absence & Brand Loyalty Presence \\
\hline \multirow[t]{5}{*}{ imageries } & happiness & 2 & 4 \\
\hline & expectations & 3 & 5 \\
\hline & satisfaction & 1 & 1 \\
\hline & certainty & 5 & 2 \\
\hline & positive associations & 4 & 3 \\
\hline \multirow[t]{4}{*}{ attitudes } & I aim to buy branded products & 12 & 13 \\
\hline & $\begin{array}{l}\text { I am interested in branded products on a } \\
\text { regular basis }\end{array}$ & 13 & 12 \\
\hline & $\begin{array}{l}\text { branded products attract my attention } \\
\text { because I consider them better }\end{array}$ & 11 & 11 \\
\hline & $\begin{array}{l}\text { branded products attract my attention } \\
\text { because I consider them more prestigious }\end{array}$ & 14 & 14 \\
\hline \multirow[t]{5}{*}{ attributes } & quality & 19 & 19 \\
\hline & creativity of ad & 16 & 16 \\
\hline & popularity & 15 & 15 \\
\hline & availability & 17 & 17 \\
\hline & innovativeness & 18 & 18 \\
\hline \multirow[t]{5}{*}{ benefits } & branded product makes me happier & 10 & 10 \\
\hline & branded product increases my social status & 6 & 8 \\
\hline & $\begin{array}{l}\text { branded product makes it easier for me to } \\
\text { get friends }\end{array}$ & 7 & 6 \\
\hline & $\begin{array}{l}\text { branded product attracts the attention } \\
\text { of others }\end{array}$ & 8 & 7 \\
\hline & branded product belongs to my lifestyle & 9 & 9 \\
\hline
\end{tabular}

Source: Authors' own research, 2019.

Factor analysis has been chosen as the main statistical tool for evaluation of the consumer's perception of brand value sources in case of brand loyalty absence vs. brand loyalty presence. This analysis is one of the group of multidimensional statistical methods which are used to create so-called factors (previously unobservable variables) to reduce the amount of originally set attributes without losing the relevant information obtained inside the data set [55,56]. Recently, this statistical tool has been used with higher frequency in the social sciences due to the boom in information technology development and the need of reducing subjectivity. The definition of the relevant statistical model as well as the identification of rational assumptions is the base of this analysis. In the process of identification of relevant factors, it is primarily important to identify and test the dependence between originally defined variables through the correlation matrix. The basic presumption for the data reduction is the correlation of these variables verified by the correlation matrix creation as well as the fulfilment of the assumption that identified correlation exists as a consequence of less undetected hidden variables (factors). Based on this, it is possible to diversify originally defined variables into partial groups. In these groups, there are unified factors which internally correlate more inside the group than in comparison with other groups. 
We assume that $\mathrm{x}$ is a $\mathrm{p}$-dimensional random vector of the considered variables with a vector of mean values $\mu$, a covariance matrix $C(X)=\Sigma$, and a correlation matrix of simple correlation coefficients $\mathrm{P}(\mathrm{X})=\mathrm{P}$. One of the basic assumptions of factor analysis is the existence of $\mathrm{R}$ common background factors $F_{1}, F_{2}, \ldots, F_{R}$; trying to have them as little as possible, preferably less than $p$. The P-dimensional random vector consists of the $j$-observable random variables $x_{j}, j=1,2, \ldots, p$; which can be expressed by Equation (1) as

$$
X_{j}=\mu_{j}+\gamma_{j 1} F_{1}+\gamma_{j 2} F_{2}+\ldots+\gamma_{j R} F_{R}+\varepsilon_{j},
$$

where $\varepsilon_{1}, \varepsilon_{2}, \ldots, \varepsilon_{p}$ are $\mathrm{p}$ stochastic error terms referred to as specific factors. If we write this in matrix, we get the Equation (2):

$$
x=\mu+\Gamma f+\varepsilon,
$$

where $\Gamma$ is a matrix of factors loadings type $\mathrm{p} \mathrm{R}$; $f$ is R-member vector of common factors, and $\varepsilon$ is p-member vector of specific factors. Factors loadings can be considered as regression coefficients $p$ of observed variables on R nonobservable factors, and when certain conditions of solution are met, they are also covariance between the original and the new variables. Factors loadings can be interpreted as the contribution of the $r$-factor of the j-specified variable, when the same units of measurement are used. To determine the adequacy of the statistical sample, we use the KMO (Kaiser-Meyer-Olkin) Test Equation (3):

$$
K M O=\frac{\sum_{j \neq j^{\prime}}^{p} \sum_{j \neq j^{\prime}}^{p} r^{2}\left(x_{j}, x_{j^{\prime}}\right)}{\sum_{j \neq j^{\prime}}^{p} \sum_{j \neq j^{\prime}}^{p} r^{2}\left(x_{j}, x_{j^{\prime}}\right)+\sum_{j \neq j^{\prime}}^{p} \sum_{j \neq j^{\prime}}^{p} r^{2}\left(x_{j}, x_{j^{\prime}} \text {. other } x\right)}
$$

where $r^{2}\left(x_{j}, x_{j^{\prime}}\right)$ are simple correlation coefficients and $r^{2}\left(x_{j}, x_{j^{\prime}}\right.$. other $\left.x\right)$ are partial correlation coefficients under the condition of statically constant remaining p-2 variables. $\left(x_{1}, x_{2}, \ldots, x_{j-1}, x_{j+1}\right.$, $\left.\ldots, x_{j^{\prime}-1}, x_{j^{\prime}+1}, x_{p}\right)$.

Required value of KMO test should be higher than 0.6. By acquiring it, the adequacy of statistical sample is proved [57]. Required value of Barlett's test of sphericity should be lower than 0.05. By acquiring it, the dependence between variables is proved [58]. Required value of Cronbach's Alpha should be higher than 0.8. By acquiring it, the intrinsic consistency of the factors is proved [59]. Detection of the optimal values of these tests forms appropriate basis to the identification of the order of brand value sources in case of loyalty absence vs. loyalty presence. Thus, a set of advices formulated on the basis of factors identification and comparison of obtained results can be submitted to the practice of sustainable brand value building and managing of alimentary goods.

\section{Results and Discussion}

Provided KMO test (Kaiser-Meyer-Olkin test) has indicated the adequacy of the used statistical sample in case of brands with consumer's loyalty absence as well as in case of brands with consumer's loyalty presence $(>0.6)$. When testing the brand value sources in case of brand loyalty absence, the value of 0.902 has been reached, and in the case of brand loyalty presence, the value of 0.931 has been reached. Barlett's test of sphericity has proved the existence of dependence between variables by acquiring the resulting value at 0.00 in case of brands with consumer's loyalty absence as well as in case of brands with consumer's loyalty presence $(<0.05)$. We have also detected statistical relevance of four relevant factors in both cases.

The testimonial value of factor analysis in case of brand value sources research when brand loyalty is absent has reached a value of $76.552 \%$. (See Table 2 ) 
Table 2. Total variance explained—brand loyalty absence.

\begin{tabular}{|c|c|c|c|c|c|c|c|c|c|}
\hline \multirow[b]{2}{*}{ Code } & \multicolumn{3}{|c|}{ Initial Eigenvalues } & \multicolumn{3}{|c|}{ Extraction Sums of Squared Loadings } & \multicolumn{3}{|c|}{ Rotation Sums of Squared Loadings } \\
\hline & Total & $\begin{array}{c}\% \text { of } \\
\text { Variance }\end{array}$ & $\begin{array}{c}\text { Cumulative } \\
\%\end{array}$ & Total & $\begin{array}{c}\% \text { of } \\
\text { Variance }\end{array}$ & $\begin{array}{c}\text { Cumulative } \\
\%\end{array}$ & Total & $\begin{array}{c}\% \text { of } \\
\text { Variance }\end{array}$ & $\begin{array}{c}\text { Cumulative } \\
\%\end{array}$ \\
\hline 1 & 9.368 & 49.303 & 49.303 & 9.368 & 49.303 & 49.303 & 4.312 & 22.694 & 22.694 \\
\hline 2 & 2.595 & 13.660 & 62.963 & 2.595 & 13.660 & 62.963 & 3.871 & 20.374 & 43.068 \\
\hline 3 & 1.380 & 7.264 & 70.228 & 1.380 & 7.264 & 70.228 & 3.233 & 17.015 & 60.083 \\
\hline 4 & 1.202 & 6.325 & 76.552 & 1.202 & 6.325 & 76.552 & 3.129 & 16.469 & 76.552 \\
\hline 5 & 0.691 & 3.637 & 80.189 & & & & & & \\
\hline 6 & 0.494 & 2.598 & 82.787 & & & & & & \\
\hline 7 & 0.446 & 2.347 & 85.134 & & & & & & \\
\hline 8 & 0.374 & 1.967 & 87.101 & & & & & & \\
\hline 9 & 0.347 & 1.824 & 88.925 & & & & & & \\
\hline 10 & 0.307 & 1.614 & 90.539 & & & & & & \\
\hline 11 & 0.289 & 1.522 & 92.061 & & & & & & \\
\hline 12 & 0.280 & 1.472 & 93.534 & & & & & & \\
\hline 13 & 0.247 & 1.300 & 94.834 & & & & & & \\
\hline 14 & 0.206 & 1.082 & 95.916 & & & & & & \\
\hline 15 & 0.194 & 1.020 & 96.936 & & & & & & \\
\hline 16 & 0.184 & 0.967 & 97.903 & & & & & & \\
\hline 17 & 0.163 & 0.857 & 98.760 & & & & & & \\
\hline 18 & 0.132 & 0.693 & 99.454 & & & & & & \\
\hline 19 & 0.104 & 0.546 & 100.000 & & & & & & \\
\hline
\end{tabular}

In case of brand loyalty absence, the existence of four relevant factors with significant components has been proved. These factors are (1) imageries with five components where the value of Cronbach's Alpha has been 0.813 ; (2) benefits with five components where the value of Cronbach's Alpha has been 0.842 ; (3) attitudes with four components where the value of Cronbach's Alpha value has been 0.849 , and (4) attributes with five components where the value of Cronbach's Alpha has been 0.813 . (See Table 3)

Table 3. Rotated component matrix-brand loyalty absence.

\begin{tabular}{|c|c|c|c|c|}
\hline \multirow{2}{*}{ Code } & \multicolumn{4}{|c|}{ Brand Value Source } \\
\hline & Imageries & Benefits & Attitudes & Attributes \\
\hline 1 & 0.855 & & & \\
\hline 2 & 0.825 & & & \\
\hline 3 & 0.790 & & & \\
\hline 4 & 0.790 & & & \\
\hline 5 & 0.784 & & & \\
\hline 6 & & 0.908 & & \\
\hline 7 & & 0.899 & & \\
\hline 8 & & 0.859 & & \\
\hline 9 & & 0.579 & 0.406 & \\
\hline 10 & 0.442 & 0.551 & & \\
\hline 11 & & & 0.798 & \\
\hline 12 & & & 0.785 & \\
\hline 13 & & 0.414 & 0.733 & \\
\hline 14 & & & 0.709 & \\
\hline 15 & & & & 0.798 \\
\hline 16 & & & & 0.784 \\
\hline 17 & & & & 0.739 \\
\hline 18 & & & & 0.664 \\
\hline 19 & 0.415 & & 0.421 & 0.594 \\
\hline
\end{tabular}

Source: Authors' own research, 2019. 
The creation of a rotated component matrix has allowed to rank the brand value sources in case of brand loyalty absence according to their priority in the impact on consumer's perception as follows: (1) imageries; (2) benefits; (3) attitudes; (4) attributes. (See Table 4)

Table 4. Brand value sources—brand loyalty absence.

\begin{tabular}{ccccc}
\hline Factors & $\begin{array}{c}\text { F1 } \\
\text { Imageries }\end{array}$ & $\begin{array}{c}\text { F2 } \\
\text { Benefits }\end{array}$ & $\begin{array}{c}\text { F3 } \\
\text { Attitudes }\end{array}$ & $\begin{array}{c}\text { F4 } \\
\text { Attributes }\end{array}$ \\
\hline N of Items & 5 & 5 & 4 & 5 \\
Cronbach's Alpha & 0.813 & 0.842 & 0.849 & 0.813 \\
\% of Variance & 49.303 & 13.660 & 7.264 & 6.325 \\
\hline
\end{tabular}

The testimonial value of factor analysis in case of brand value sources research when brand loyalty is present has reached a value of $74.614 \%$. (See Table 5)

Table 5. Total variance explained-brand loyalty presence.

\begin{tabular}{|c|c|c|c|c|c|c|c|c|c|}
\hline \multirow[b]{2}{*}{ Code } & \multicolumn{3}{|c|}{ Initial Eigenvalues } & \multicolumn{3}{|c|}{ Extraction Sums of Squared Loadings } & \multicolumn{3}{|c|}{ Rotation Sums of Squared Loadings } \\
\hline & Total & $\begin{array}{c}\% \text { of } \\
\text { Variance }\end{array}$ & $\begin{array}{c}\text { Cumulative } \\
\%\end{array}$ & Total & $\begin{array}{c}\% \text { of } \\
\text { Variance }\end{array}$ & $\underset{\%}{\text { Cumulative }}$ & Total & $\begin{array}{c}\% \text { of } \\
\text { Variance }\end{array}$ & $\begin{array}{c}\text { Cumulative } \\
\%\end{array}$ \\
\hline 1 & 9.500 & 50.002 & 50.002 & 9.500 & 50.002 & 50.002 & 4.177 & 21.982 & 21.982 \\
\hline 2 & 2.080 & 10.949 & 60.951 & 2.080 & 10.949 & 60.951 & 3.941 & 20.741 & 42.723 \\
\hline 3 & 1.456 & 7.665 & 68.616 & 1.456 & 7.665 & 68.616 & 3.125 & 16.446 & 59.170 \\
\hline 4 & 1.140 & 6.001 & 74.617 & 1.140 & 6.001 & 74.617 & 2.935 & 15.448 & 74.617 \\
\hline 5 & 0.685 & 3.606 & 78.223 & & & & & & \\
\hline 6 & 0.480 & 2.527 & 80.751 & & & & & & \\
\hline 7 & 0.425 & 2.235 & 82.986 & & & & & & \\
\hline 8 & 0.413 & 2.171 & 85.157 & & & & & & \\
\hline 9 & 0.392 & 2.061 & 87.218 & & & & & & \\
\hline 10 & 0.359 & 1.889 & 89.106 & & & & & & \\
\hline 11 & 0.309 & 1.625 & 90.732 & & & & & & \\
\hline 12 & 0.294 & 1.547 & 92.279 & & & & & & \\
\hline 13 & 0.280 & 1.473 & 93.752 & & & & & & \\
\hline 14 & 0.261 & 1.372 & 95.124 & & & & & & \\
\hline 15 & 0.247 & 1.301 & 96.426 & & & & & & \\
\hline 16 & 0.222 & 1.169 & 97.595 & & & & & & \\
\hline 17 & 0.171 & 0.899 & 98.494 & & & & & & \\
\hline 18 & 0.151 & 0.797 & 99.291 & & & & & & \\
\hline 19 & 0.135 & 0.709 & 100.000 & & & & & & \\
\hline
\end{tabular}

In case of brand loyalty presence, the existence of four relevant factors with significant components has been proved. These factors are (1) imageries with five components where the value of Cronbach's Alpha has been 0.854; (2) benefits with five components where the value of Cronbach's Alpha has been 0.837 ; (3) attitudes with four components where the value of Cronbach's Alpha value has been 0.841 and (4) attributes with five components where the value of Cronbach's Alpha has been 0.869 . (See Table 6) 
Table 6. Rotated component matrix-brand loyalty presence.

\begin{tabular}{|c|c|c|c|c|}
\hline \multirow{2}{*}{ Code } & \multicolumn{4}{|c|}{ Brand Value Source } \\
\hline & Imageries & Benefits & Attitudes & Attributes \\
\hline 1 & 0.800 & & & \\
\hline 2 & 0.781 & & & \\
\hline 3 & 0.776 & & & \\
\hline 4 & 0.767 & & & \\
\hline 5 & 0.751 & & & \\
\hline 6 & & 0.880 & & \\
\hline 7 & & 0.860 & & \\
\hline 8 & & 0.850 & & \\
\hline 9 & & 0.604 & & \\
\hline 10 & 0.521 & 0.531 & & \\
\hline 11 & & & 0.812 & \\
\hline 12 & & & 0.784 & \\
\hline 13 & & & 0.762 & \\
\hline 14 & & 0.437 & 0.643 & \\
\hline 15 & & & & 0.784 \\
\hline 16 & & & & 0.752 \\
\hline 17 & & & & 0.747 \\
\hline 18 & & & & 0.586 \\
\hline 19 & 0.417 & & 0.411 & 0.559 \\
\hline
\end{tabular}

Source: Authors' own research, 2019.

The creation of a rotated component matrix has allowed ranking the brand value sources in case of brand loyalty presence according to their priority in the impact on consumer's perception as follows: (1) imageries; (2) benefits; (3) attitudes; (4) attributes. (See Table 7)

Table 7. Brand value sources—brand loyalty presence.

\begin{tabular}{ccccc}
\hline Factors & $\begin{array}{c}\text { F1 } \\
\text { Imageries }\end{array}$ & $\begin{array}{c}\text { F2 } \\
\text { Benefits }\end{array}$ & $\begin{array}{c}\text { F3 } \\
\text { Attitudes }\end{array}$ & $\begin{array}{c}\text { F4 } \\
\text { Attributes }\end{array}$ \\
\hline N of Items & 5 & 5 & 4 & 5 \\
Cronbach's Alpha & 0.854 & 0.837 & 0.841 & 0.869 \\
\% of Variance & 50.002 & 10.949 & 7.665 & 6.001 \\
\hline
\end{tabular}

Source: Authors' own research, 2019.

Thus, it is possible to make the conclusion that importance of factors does not vary across analyzed categories of brands of alimentary goods (i.e., brand loyalty absence vs. presence). For detailed information, see Table 8 .

Table 8. Ranking of groups of components in analyzed categories.

\begin{tabular}{ccc}
\hline \multirow{2}{*}{ Rank } & Brand Loyalty Absence & Brands \\
& Imageries & Imageries \\
1 & Benefits & Benefits \\
2 & Attitudes & Attitudes \\
3 & Attributes & Attributes \\
\hline
\end{tabular}

Source: Authors' own research, 2019.

As it is obvious, the brand value sources ranking created on the basis of their priority in the impact on consumer's perception in case of brands with consumer's loyalty absence is the same as in case of brands with consumer's loyalty presence. However, when analyzing groups of components deeply, we can see that differences exist. The internal ranking inside identified groups of components is equal only in case of the less important group of brand value sources-in case of attributes. All others brand value 
sources are internally different from the point of view of relevance of individual components of these groups of brand value sources. The most visible example can be seen in scope of imageries, where only one component of brand value sources has the same ranking in case of brand loyalty absence and in case of brand loyalty presence. Thus, in case of brand loyalty absence, the order is the following: (1) satisfaction; (2) happiness; (3) expectations; (4) positive associations, and (5) certainty, while in case of brand loyalty presence, the order is the following: (1) satisfaction; (2) certainty; (3) positive associations; (4) happiness, and (5) expectations. This finding indicates the need of a selective approach to brand value sources and implementation of so far defined patterns in the practice of brand management.

While in both cases satisfaction is considered a main component in case of brands of alimentary goods, complementary components should be used differently. In case of brand value absence (similarly in phase of brand value building), it is happiness and expectations which should be mainly used, while in case of brand value presence (similarly in phase of brad value managing), it is certainty and positive associations. In case of benefits, the order is also mixed - in case of brand loyalty absence, the most important component is the ability to increase social status, while in case of brand loyalty presence, it is the ability to make it easier to get friends. Based on these findings, it is crucial to unify the consumer's satisfaction (as a main component of the most important brand value source) with corporate social responsibility and to implement sustainable managerial tools focused on stimulation of the consumer's socially conformal behavior, mainly on the basis of this brand value source. For detailed information about internal order of components inside identified brand value sources of alimentary goods, see Table 9 as a modification of Table 1.

Table 9. Brand value sources and components.

\begin{tabular}{|c|c|c|}
\hline \multirow{2}{*}{ Brand Value Sources } & \multicolumn{2}{|c|}{ Components of Brand Value Sources } \\
\hline & Brand Loyalty Absence & Brand Loyalty Presence \\
\hline imageries & $\begin{array}{c}\text { satisfaction } \\
\text { happiness } \\
\text { expectations } \\
\text { positive associations } \\
\text { certainty }\end{array}$ & $\begin{array}{c}\text { satisfaction } \\
\text { certainty } \\
\text { positive associations } \\
\text { happiness } \\
\text { expectations }\end{array}$ \\
\hline \multirow[t]{4}{*}{ benefits } & branded product increases my social status & $\begin{array}{c}\text { branded product makes it easier for me to get } \\
\text { friends }\end{array}$ \\
\hline & $\begin{array}{l}\text { branded product makes it easier for me to get } \\
\text { friends }\end{array}$ & $\begin{array}{c}\text { branded product attracts the attention of } \\
\text { others }\end{array}$ \\
\hline & $\begin{array}{c}\text { branded product attracts the attention of } \\
\text { others }\end{array}$ & branded product increases my social status \\
\hline & $\begin{array}{l}\text { branded product belongs to my lifestyle } \\
\text { branded product makes me happier }\end{array}$ & $\begin{array}{l}\text { branded product belongs to my lifestyle } \\
\text { branded product makes me happier }\end{array}$ \\
\hline \multirow[t]{4}{*}{ attitudes } & $\begin{array}{l}\text { branded products attract my attention } \\
\text { because I consider it better }\end{array}$ & $\begin{array}{l}\text { branded products attract my attention } \\
\text { because I consider it better }\end{array}$ \\
\hline & I aim to buy branded products & $\begin{array}{l}\text { I am interested in branded product on a } \\
\text { regular basis }\end{array}$ \\
\hline & $\begin{array}{c}\text { I am interested in branded products on a } \\
\text { regular basis }\end{array}$ & I aim to buy branded products \\
\hline & $\begin{array}{l}\text { branded products attract my attention } \\
\text { because I consider them more prestigious }\end{array}$ & $\begin{array}{l}\text { branded products attract my attention } \\
\text { because I consider them more prestigious }\end{array}$ \\
\hline attributes & $\begin{array}{c}\text { popularity } \\
\text { creativity of ad } \\
\text { availability } \\
\text { innovativeness } \\
\text { quality }\end{array}$ & $\begin{array}{c}\text { popularity } \\
\text { creativity of ad } \\
\text { availability } \\
\text { innovativeness } \\
\text { quality }\end{array}$ \\
\hline
\end{tabular}

Source: Authors' own research, 2019.

Another important dimension of these findings lies in the differences between the order of brand value sources which have been identified generally and in case of alimentary goods. In case of brand loyalty absence, both categories are characterized by imageries as a main brand value source, while in case of brand loyalty presence, imageries are the most important only for brands of alimentary goods. Generally, imageries have been replaced by benefits. Thus, the need of a selective approach to sustainable brand management across product categories which has been so far only assumed, has been definitely proved [45-50,52]. For detailed information, see Table 10. 
Table 10. Comparative ranking of grouped brand value components (in general/alimentary goods).

\begin{tabular}{ccccc}
\hline \multirow{2}{*}{ Rank } & \multicolumn{2}{c}{ Brand Loyalty Absence } & \multicolumn{2}{c}{ Brand Value Sources } \\
Brand Loyalty Presence \\
& In General & Alimentary Goods & In General & Alimentary Goods \\
\hline 1 & Imageries & Imageries & Benefits & Imageries \\
\hline 2 & Attitudes & Benefits & Attributes & Benefits \\
\hline 3 & Benefits & Attitudes & Imageries & Attitudes \\
\hline 4 & Attributes & Attributes & Attitudes & Attributes \\
\hline
\end{tabular}

Practical implications of these results indicate that imageries are the leading brand value source in case of brand loyalty absence regardless of the category of product (i.e., in general or in case of alimentary goods). On the contrary, in case of brand loyalty presence, the leading brand value source with significant impact on brand value subjectively perceived by consumer is benefits, while in case of alimentary goods, imageries remain to be the most relevant brand value source. According to this fact, we can observe these main findings: (1) in general, brand value sources vary due to the phase of brand management, while in case of alimentary goods, brand value sources remain identical; (2) the position of brand loyalty is ambivalent when applying point of view of stimuli vs. point of view of obstacle to prospective sustainable brand management, and (3) traditional general patterns of sustainable brand management are inapplicable in case of brands of alimentary goods.

Thus, we can state that the process of brand value building and management in case of alimentary goods does not have to be selective if it is connected with the phase of brand value building or brand value management (taking brand value sources into account and not their components). This coherent approach facilitates the managerial practice of brands of alimentary goods, where it is enough to identify relevant components of imageries as the most important brand value sources (happiness, expectations, satisfaction, certainty, and positive associations) at the very beginning of the process of brand value building, and these components can be subsequently used during all the brand life cycle. A representative product which declares the applicability of this approach is Coca-Cola, which is systematically built on the basis of joy and happiness as the leading brand value pillars.

On the other hand, as it has not been identified the difference between brand value sources of alimentary goods regarding to the presence vs. absence of brand loyalty, we cannot conclude that its existence is vital in the process of sustainable brand management. It means that managers of brands of alimentary goods should not expect bigger receptivity of sustainable brand management activities by the customers in case of brand loyalty presence. In other words, if the transition to sustainable brand management is done and the consumer identifies that it is not in accordance with brand value source accented so far, the brand value could be harmed.

The fact that we have identified the difference between brand value sources in case of brand loyalty presence vs. brand loyalty absence among categories verifies the presumption that universal sustainable brand management patterns should not be applied, as individual product categories are specific, and the modification of formulated models and processes of sustainable brand management should be supported by further market, opinion, and social research to arrange optimal applicability and effective goal fulfilment in scope of sustainable brand management.

We have confirmed that the main task for managers of not only formally but really sustainably manageable brands is to identify internal motives and brand value sources of their consumers and to co-act in the process of market education as one of the prerequisites of socially sustainable development [17,61]. Similarly, we verified the importance of satisfaction-affected trust and brand loyalty in the category of alimentary goods $[23,24]$. On the other hand, we have rejected the theory which highlights the importance of emotional sources of brand value. Thus, the scientific gap lying in the need of the mechanisms of behavioral economics investigation has been disputed [21]. In scope of these facts, it is also disputable the phenomenon of so-called love brands and its effectiveness in the 
process of brand loyalty creation and management [22]. When analyzing these findings, it is possible to apply specific point of view based on the regional psychographic specifics of consumers [34-39]. It is because we have accepted theories from authors who investigated regionally closer markets, while the theories of other authors have been rejected. Such a specific attitude of Slovak consumers to the brands of alimentary goods can be the reason of the phenomenon of double quality of food, which is typical for Slovak market in comparison with other markets of neighbor countries (mainly Austria). Surprisingly, although double quality has been clearly proven by independent tests, Slovak consumers do not change their attitudes towards brands and they follow their buying habits. This fact is extremely dangerous in scope of sustainable brand management concept implementation because brands of alimentary goods which are subjectively perceived as valuable are not motivated enough to behave responsibly towards society, and consumers do not have motivation to be active in the process of information searching. Thus, it is extremely important to analyze value sources of brands characterized by presence vs. absence of consumer loyalty and to apply a conscious and responsible approach to the consumer's loyalty as to the one of the leading buying behavior motives. However, there are still possibilities for further research that should be focused in more detail on the specifics of consumer segmentation. A possible way to obtain brand management benefits in this case is the application of the generation approach. It is because we can suppose that the ranking of brand value sources and their components in case of alimentary goods varies if analyzing Generations $X, Y$, and Z.

\section{Conclusions}

Until now, the phenomenon of brand loyalty has not been analyzed in details connected with possible negative impact on sustainable development. Thus, the main aim of the article is to identify brand value sources of loyalty which are relevant to sustainable brand management of alimentary goods. To achieve this aim, we have used the data from our own research provided on the socio-demographically representative sample of 2000 respondents (sample without outliers, and incompatible units was 697) during the first half of the year 2019. We have realized this research via a questionnaire survey in the form of computer-assisted web interviewing. The questionnaire was administered in Slovak Republic among its inhabitants aged over 15 years who have been asked to fulfil the questionnaire because of their legal labor subjectivity. Thus, the main presumption of autonomous buying decision-making has been fulfilled. To provide research of brand value sources in scope of buying behavior typology, traditional quadratic typology of buying behavior has been used, where based on the degree of engagement and differentiation, obtained data were statistically evaluated by the factor analysis supported by relevant statistical tests (KMO Test, Barlett's test of sphericity, and calculation of Cronbach's Alpha). Based on this, it has been possible to identify relevant brand value sources of alimentary goods in case of brand loyalty absence as well as brand loyalty presence. It has not been proved the existence of significant difference between brand value sources ranking according to their priority in the impact on the consumer's perception in case of loyal and nonloyal consumers. The order of the brand value sources has been in both cases following (1) imageries; (2) benefits; (3) attitudes, and (4) attributes. However, when analyzing groups of components deeply, we can see that differences exist. The internal ranking inside identified groups of components is equal only in case of the less important group of brand value sources-in case of attributes. All others brand value sources are internally different from the point of view of relevance of individual components of these groups of brand value sources. The most visible example can be seen in scope of imageries, where only one component of brand value sources has the same ranking in case of brand loyalty absence and in case of brand loyalty presence. From a managerial point of view, these findings are even more important as they provide more details potentially used in scope of sustainable brand management of alimentary goods. Even though the conclusions formulated on the basis of provided research obtain useful information for the practice of sustainable brand management, there have been identified various relevant limitations of the research. The most important is the territorial validity of the research. These findings are fully applicable only in case of Slovak consumer, meaning that in case of entering Slovak company on 
foreign market, these findings have to be critically re-evaluated in scope of specifics of selected market. When respecting this fact, managers have to their disposal a very wide portfolio of information usable in all the portfolio of sustainable brand management implications. Not only valuable introspection into the previous practical successes and fails of brands is provided, but also the platform for optimal managerial decision-making in the future is created. In scope of the above mentioned, provided research offers the information relevant to appropriate setting of the content communicated with the consumers according to their identified preferences, demands, and expectations. The main managerial recommendation consists of the fact that "imageries" have been detected as a most valuable source of brand value from the consumer's point of view. This source consists of happiness, expectations, satisfaction, certainty, and positive associations as its relevant components. That is to say, these are the basic pillars of subjectively perceived brand value which should be systematically used in the process of sustainable brand management of alimentary goods in all its complexity. It means that there is no need to distinguish between the process of brand value building and the process of brand value management as the main brand value source does not change.

The outcomes of the research and subsequently formulated conclusions provide the understanding of overall complexity of internal and external factors which motivates consumers to be interested in strong and functional interaction with brand. These findings have already been partially outlined by various authors, but no clear and uniform statement has been formulated thus far in the scope of sustainable brand value management of alimentary goods and the individual brand value sources. We have mainly verified the importance of satisfaction affected by trust, and brand loyalty in the category of alimentary goods, but on the other hand, we have rejected existing theory which highlights the importance of emotional sources of brand value.

Regardless of the declared importance and usability of the research results, there are still many points of view which could enrich its managerial applicability. One of them is the consideration of generational stratification and critical discussion of specifics of the consumer's brand value perception in the light and shadow of sustainable brand management optimal implementation.

Author Contributions: J.M. and A.K. designed the experiments. M.N. and L.G. analysed the data. G.L. contributed analysis tools. J.K. and W.S. wrote the paper. All authors have read and agreed to the published version of the manuscript.

Funding: This contribution is a partial output of scientific project APVV-15-0505: Integrated model of management support for building and managing the brand value in the specific conditions of the Slovak Republic.

Conflicts of Interest: The authors declare no conflict of interest.

\section{References}

1. Oh, W.-Y.; Choi, K.J.; Chang, Y.K.; Jeon, M.-K. MNEs' Corporate Social Responsibility: An Optimal Investment Decision Model. Eur. J. Int. Manag. 2019, 13, 307-327. [CrossRef]

2. Popadic, I.; Borocki, J.; Radisic, M.; Stefanic, I.; Duspara, L. The Challenges While Measuring Enterprise Innovative Activities-The Case from a Developing Country. Teh. Vjesn. Tech. Gaz. 2018, 25, 452-459. [CrossRef]

3. Zvirgzdina, R.; Linina, I.; Vevere, V. Efficient Consumer Response (ECR) Principles and Their Application in Retail Trade Enterprises in Latvia. Eur. Integr. Stud. 2015, 9, 257-264. [CrossRef]

4. Gonzalez-Ramos, M.I.; Donate, M.J.; Guadamillas, F. An Empirical Study on the Link Between Corporate Social Responsibility and Innovation in Environmentally Sensitive Industries. Eur. J. Int. Manag. 2018, 12, 402-422. [CrossRef]

5. Bellucci, M.; Bini, L.; Giunta, F. Implementing Environmental Sustainability Engagement into Business: Sustainability Management, Innovation, and Sustainable Business Models. Innov. Strateg. Environ. Sci. 2020, 107-143. [CrossRef]

6. Demir, M.; Lenhart, S. Optimal sustainable fishery management of the Black Sea anchovy with food chain modeling framework. Nat. Resour. Modeling 2019, e12253. [CrossRef] 
7. Vafaei, S.; Bazrkar, A.; Hajimohammadi, M. The Investigation of the Relationship Between Sustainable Supply Chain Management and Sustainable Competitive Advantage According to the Mediating Role of Innovation and Sustainable Process Management. Braz. J. Oper. Prod. Manag. 2019, 16, 572-580. [CrossRef]

8. De los Salmones, M.D.G.; Crespo, A.H.; del Bosque, I.R. Influence of Corporate Social Responsibility on Loyalty and Valuation of Services. J. Bus. Ethics 2005, 61, 369-385. [CrossRef]

9. Ganushchak-Efimenko, L.; Shcherbak, V.; Nifatova, O. Assessing the Effects of Socially Responsible Strategic Partnerships on Building Brand Equity of Integrated Business Structures in Ukraine. Oeconomia Copernic. 2018, 9, 715-730. [CrossRef]

10. Zhulega, I.A.; Gagulina, N.L.; Samoylov, A.V.; Novikov, A.V. Problems of Corporate Economics and Sustainable Development in the Context of the Sanction World Order: Living Standards and Live Quality. Ekon. Manaz. Spektrum 2019, 13, 83-95. [CrossRef]

11. Gillespie, B.; Rogers, M.M. Sustainable Supply Chain Management and the End User: Understanding the Impact of Socially and Environmentally Responsible Firm Behaviors on Consumers' Brand Evaluations and Purchase Intentions. J. Mark. Channels 2016, 23, 34-46. [CrossRef]

12. Dumitriu, D.; Militaru, G.; Deselnicu, D.C.; Niculescu, A.; Popescu, M.A.M. A Perspective Over Modern SMEs: Managing Brand Equity, Growth and Sustainability Through Digital Marketing Tools and Techniques. Sustainability 2019, 11, 2111. [CrossRef]

13. Hu, D.; Wang, Y.D.; Yang, X. Trading Your Diversification Strategy for a Green One: How Do Firms in Emerging Economies Get on the Green Train? Organ. Environ. 2019, 32, 391-415. [CrossRef]

14. Lu, J.T.; Ren, L.C.; He, Y.F.; Lin, W.F.; Streimikis, J. Linking Corporate Social Responsibility with Reputation and Brand of the Firm. Amfiteatru Econ. 2019, 21. [CrossRef]

15. Drugau-Constantin, A. Emotional and Cognitive Reactions to Marketing Stimuli: Mechanisms Underlying Judgments and Decision Making in Behavioral and Consumer Neuroscience. Econ. Manag. Financ. Mark. 2018, 13, 46-50. [CrossRef]

16. Torres, A.; Bijmolt, T.H.A.; Tribo, J.A.; Verhoef, P. Generating Global Brand Equity through Corporate Social Responsibility to Key Stakeholders. Int. J. Res. Mark. 2012, 29, 13-24. [CrossRef]

17. Grubor, A.; Milovanov, O. Brand Strategies in the Era of Sustainability. Interdiscip. Descr. Complex. Syst. 2017, 15, 78-88. [CrossRef]

18. Riera, M.; Iborra, M. Corporate Social Irresponsibility: Review and Conceptual Boundaries. Eur. J. Manag. Bus. Econ. 2017, 26, 146-162. [CrossRef]

19. Bhattacharya, C.B.; Sen, S. Doing Better at Dong Good: When, Why, and How Consumers Respond to Corporate Social Initiatives. Calif. Manag. Rev. 2004, 47, 9-24. [CrossRef]

20. Hur, W.M.; Kim, H.; Woo, J. How CSR Leads to Corporate Brand Equity: Mediating Mechanisms of Corporate Brand Credibility and Reputation. J. Bus. Ethics 2014, 125, 75-86. [CrossRef]

21. Castro-Gonzalez, S.; Bande, B.; Fernandez-Ferrin, P.; Kimura, T. Corporate Social Responsibility and Consumer Advocacy Behaviors: The Importance of Emotions and Moral Virtues. J. Clean. Prod. 2019, 231, 846-855. [CrossRef]

22. Song, H.; Wang, J.; Han, H. Effect of Image, Satisfaction, Trust, Love, and Respect on Loyalty Formation for Name-brand Coffee Shops. Int. J. Hosp. Manag. 2019, 79, 50-59. [CrossRef]

23. Olah, J.; Karmazin, G.Y.; Farkasne Fekete, M.; Popp, J. An Examination of Trust as a Strategical Factor of Success in Logistical Firms. Bus. Theory Pract. 2017, 18, 171-177. [CrossRef]

24. Olah, J.; Sadaf, R.; Mate, D.; Popp, J. The Influence of the Management Success Factors of Logistics Service Providers on Firms' Competitiveness. Pol. Jounal Manag. Stud. 2018, 17, 175-193. [CrossRef]

25. Rivera, J.J.; Bigne, J.; Curras-Perez, R. Effects of Corporate Social Responsibility on Consumer Brand Loyalty. Rbgn-Rev. Bras. De Gest. De Neg. 2019, 21, 395-415. [CrossRef]

26. Vevere, V.; Sannikova, A. Developing Intercultural Negotiations Skills to Meet Current Challenges of Diverse EU Business Environment as Part of University Social Responsibility. Eur. Integr. Stud. 2018, 12, 8-18. [CrossRef]

27. Chadhuri, A.; Holbrook, M.B. The Chain of Effects from Brand Trust and Brand Affect to Brand Performance: The Role of Brand Loyalty. J. Mark. 2001, 65, 81-93. [CrossRef]

28. Bhattacharya, C.B.; Sen, S. Consumer-company Identification: A Framework for Understanding Consumers' Relationships with Companies. J. Mark. 2003, 67, 76-88. [CrossRef] 
29. Stocchi, L.; Fuller, R. A Comparison of Brand Equity Strength Across Consumer Segments and Markets. J. Prod. Brand Manag. 2017, 26, 453-468. [CrossRef]

30. Curras-Perez, R.; Dolz-Dolz, C.; Sanchez-Garcia, I. How Social, Environmental, and Economic CSR Affects Consumer-Perceived Value: Does Perceived Consumer Effectiveness Make a Difference? Corp. Soc. Responsib. Environ. Manag. 2018, 25, 733-747. [CrossRef]

31. Yang, C.Y.; Yang, C.H. The Impact of Sustainable Environmental Management in the Food and Beverage Industry on Customer Loyalty: A View of Brand Attitude. Ekoloji 2019, 28, 965-972.

32. Abdullah, M.I.; Sarfraz, M.; Arif, A.; Azam, A. An Extension of the Theory of Planned Behavior Towards Brand Equity and Premium Price. Pol. J. Manag. Stud. 2018, 18, 20-32. [CrossRef]

33. Popp, J.; Olah, J.; Kiss, A.; Lakner, Z. Food Security Perspectives in Sub-Saharan Africa. Amfiteatru Econ. 2019, 21, 361-376. [CrossRef]

34. Chatzipanagiotou, K.; Christodoulides, G.; Veloutsou, C. Managing the Consumer-based Brand Equity Process: A Cross-cultural Perspective. Int. Bus. Rev. 2019, 28, 328-343. [CrossRef]

35. Sukalova, V.; Ceniga, P.; Janotova, H. Harmonization of Work and Family Life in Company Management in Slovakia. Procedia Econ. Financ. 2015, 26, 152-159. [CrossRef]

36. Tamuliene, V.; Pilipavicius, V. Research in Customer Preferences Selecting Insurance Services: A Case Study of Lithuania. Forum Sci. Oeconomia 2017, 5, 49-58. [CrossRef]

37. Rozgina, L. The Latvian Audit Services Market: Current Issues and Challenges. Forum Sci. Oeconomia 2018, 6, 7-21. [CrossRef]

38. Jain, T.; Zaman, R. When Boards Matter: The Case of Corporate Social Irresponsibility. Br. J. Manag. 2019. [CrossRef]

39. Christodoulides, G.; Cadogan, J.W.; Veloutsou, C. Consumer-based Brand Equity Measurement: Lessons Learned from an International Study. Int. Mark. Rev. 2015, 32, 307-328. [CrossRef]

40. Rather, R.A.; Tehseen, S.; Itoo, M.H.; Parrey, S.H. Customer Brand Identification, Affective Commitment, Customer Satisfaction, and Brand Trust as Antecedents of Customer Behavioral Intention of Loyalty: An Empirical Study in the Hospitality Sector. J. Glob. Sch. Mark. Sci. 2019, 29, 196-217. [CrossRef]

41. Poushneh, A.; Vasquez-Parraga, A.Z. Emotional Bonds with Technology: The Impact of Customer Readiness on Upgrade Intention, Brand Loyalty, and Affective Commitment through Mediation Impact of Customer Value. J. Theor. Appl. Electron. Commer. Res. 2019, 14, 90-105. [CrossRef]

42. Dawes, J.; Meyer-Waarden, L.; Driesener, C. Has Brand Loyalty Declined? A Longitudinal Analysis of Repeat Purchase Behavior in the UK and the USA. J. Bus. Res. 2015, 68, 425-432. [CrossRef]

43. Smith, A.; Stirling, A. Innovation, Sustainability and Democracy: An Analysis of Grassroots Contributions. J. Self-Gov. Manag. Econ. 2018, 6, 64-97. [CrossRef]

44. Brunner, T.A.; Stocklin, M.; Opwis, K. Satisfaction, Image and Loyalty: New Versus Experienced Customers. Eur. J. Mark. 2008, 42, 1095-1105. [CrossRef]

45. Alvarado-Herrera, A.; Bigne, E.; Aldas-Manzano, J.; Curras-Perez, R. A Scale for Measuring Consumer Perceptions of Corporate Social Responsibility Following the Sustainable Development Paradigm. J. Bus. Ethics 2017, 140, 243-262. [CrossRef]

46. Hafez, M. Measuring the Impact of Corporate Social Responsibility Practices on Brand Equity in the Banking Industry in Bangladesh the Mediating Effect of Corporate Image and Brand Awareness. Int. J. Bank Mark. 2018, 36. [CrossRef]

47. Long, C.Z.; Lin, J. The Impact of Corporate Environmental Responsibility Strategy on Brand Sustainability: An Empirical Study Based on Chinese Listed Companies. Nakai Bus. Rev. Int. 2018, 9, 366-394. [CrossRef]

48. Alcaide, M.A.; De La Poza, E.; Guadalajara, N. Assessing the Sustainability of High-Value Brands in the IT Sector. Sustainability 2019, 11, 1598. [CrossRef]

49. Pinto, D.C.; Herter, M.M.; Goncalves, D.; Savin, E. Can Luxury Brands Be Ethical? Reducing the Sophistication Liability of Luxury Brands. J. Clean. Prod. 2019, 233, 1366-1376. [CrossRef]

50. Tofighi, M.; Bodur, H.O. Social Responsibility and its Differential Effects on the Retailers' Portfolio of Private Label Brands. Int. J. Retail. Distrib. Manag. 2015, 43, 301-313. [CrossRef]

51. Lizbetinova, L. The Quality of Communication in the Context of Regional Development. Deturope-Cent. Eur. J. Reg. Dev. Tour. 2014, 6, 22-38.

52. Casteran, G.; Chrysochou, P.; Meyer-Waarden, L. Brand loyalty evolution and the impact of category characteristics. Mark. Lett. 2019, 30, 57-73. [CrossRef] 
53. Sukalova, V.; Ceniga, P. Customer Protection in the Field of Life Insurance. Lect. Notes Manag. Sci. 2017, 73, 17-22. [CrossRef]

54. Kolnhofer Derecskei, A. Relations between Risk Attitudes, Culture and the Endowment Effect. Eng. Manag. Prod. Serv. 2018, 10, 7-20. [CrossRef]

55. Berzakova, V.; Bartosova, V.; Kicova, E. Modification of EVA in Value Based Management. Procedia Econ. Financ. 2015, 26, 317-324. [CrossRef]

56. Lizbetinova, L.; Starchon, P.; Lorincova, S.; Weberova, D.; Prusa, P. Application of Cluster Analysis in Marketing Communications in Small and Medium-Sized Enterprises: An Empirical Study in the Slovak Republic. Sustainability 2019, 11, 2302. [CrossRef]

57. Tuffnell, C.; Kral, P.; Durana, P.; Krulicky, T. Industry 4.0-based Manufacturing Systems: Smart Production, Sustainable Supply Chain Networks, and Real-time Process Monitoring. J. Self-Gov. Manag. Econ. 2019, 7, 7-12. [CrossRef]

58. Popescu Ljungholm, D. Employee-employer Relationships in the Gig Economy: Harmonizing and Consolidating Labor Regulations and Safety Nets. Contemp. Read. Law Soc. Justice 2018, 10, 144-150. [CrossRef]

59. Svabova, L.; Kramarova, K.; Durica, M. Prediction Model of Firm’S Financial Distress. Ekon. Manaz. Spektrum 2018, 12, 16-29. [CrossRef]

60. Kliestikova, J.; Kovacova, M.; Krizanova, A.; Durana, P.; Nica, E. Quo Vadis Brand Loyalty? Comparative Study of Perceived Brand Value Sources. Pol. J. Manag. Stud. 2019, 19, 190-203. [CrossRef]

61. Krylov, S. Strategic Customer Analysis Based on Balanced Scorecard. Ekon. Manaz. Spektrum 2019, 13, $12-25$. [CrossRef]

(C) 2020 by the authors. Licensee MDPI, Basel, Switzerland. This article is an open access article distributed under the terms and conditions of the Creative Commons Attribution (CC BY) license (http://creativecommons.org/licenses/by/4.0/). 